\title{
TAXONOMY AND NOMENCLATURE OF THREE CLOSELY RELATED SPECIES OF ELEOCHARIS SUBGENUS LIMNOCHLOA (CYPERACEAE)
}

\author{
D.J. ROSEN ${ }^{1}$, S.L. HATCH ${ }^{1} \&$ R. CARTER ${ }^{2}$
}

\begin{abstract}
SUMMARY
A taxonomic synopsis and review of nomenclature is provided for Eleocharis cellulosa, E. mutata, and $E$. spiralis, three closely related species belonging to subgenus Limnochloa. One heterotypic synonym of $E$. mutata and the basionym and a heterotypic synonym of E. spiralis are lectotypified. The taxonomic treatment includes a key, detailed descriptions and synonymy for each species, notes on distribution and habitat, and illustrations prepared from selected specimens.
\end{abstract}

Key words: Cyperaceae, Eleocharis, Limnochloa, lectotypification, nomenclature.

\section{INTRODUCTION}

Eleocharis R.Br. is a cosmopolitan genus of \pm 200 species and over 600 published names with the major centre of diversity in the Neotropics (González-Elizondo \& Tena-Flores 2000). Eleocharis subg. Limnochloa (P.Beauv. ex T.Lestib.) Torr. (= Eleocharis ser. Mutatae Svenson) consists of over 35 aquatic or wetland species distributed throughout tropical and subtropical regions worldwide and are distinguished from other Eleocharis by a combination of the following morphological characters: indurate to cartilaginous floral scales marginally and distally translucent hyaline-erose and with numerous adaxial cellular-lineate to prominently raised longitudinal veins; proximal scale appearing as a continuation of the culm; coarse culms variously sharply angled to terete and often as thick as the cylindrical spikelet; and biconvex (rarely trigonous) achenes usually with large polygonal epidermal cells arranged in longitudinal rows (González-Elizondo \& Peterson 1997). The subgenus has received little attention since the formative work of Svenson $(1929,1939)$ aside from the description of several new species (GonzálezElizondo \& Reznicek 1996, Roalson 1999, Trevisan \& Boldrini 2006, Rosen \& Hatch 2007) and a few geographically limited studies (Klimko 1988, Browning et al. 1997), and is in need of worldwide revision.

Recent research by Rosen (2006) supports Svenson's (1939) view that Eleocharis cellulosa Torr., E. mutata (L.) Roem. \& Schult., and E. spiralis (Rottb.) Roem. \& Schult. form a closely related group sharing the following morphological characters and ecological affinity: floral scales indurate, adaxially many cellular-lineate veined; achene

1) S.M. Tracy Herbarium, Department of Ecosystem Science \& Management, Texas A\&M University, College Station, TX 77843-2126, USA.

2) Herbarium, Department of Biology, Valdosta State University, Valdosta, Georgia 31698-0015, USA. 
apex slightly constricted at the summit into a hard annular thickening or gradually narrowed spongy beak of the same texture and colour as the achene; distal leaf sheath apices that are prolonged into slender, soft awns; achene epidermal cells with concave and distinctly and deeply undulating inner periclinal walls and usually numerous lumen pits; and a distribution in coastal, usually brackish or saline wetlands. The purpose of this paper is to provide an updated taxonomic treatment of these three species based on data from field work in México and the south-eastern United States and on a study of over 700 herbarium specimens (including types) from BM, BRI, BRIT, C, CIIDIR, CM, E, F, GA, GH, K, LIV, LL, M, MEXU, MICH, MO, NU, NY, P, PH, PRE, RSA, SBSC, SMU, SWT, TAES, TEX, US, USF, VSC, WIS, Z, and ZT (acronyms follow Holmgren et al. 1990). Complete citations of all specimens studied can be found in Rosen (2006).

\section{TAXONOMIC TREATMENT}

\section{KEY TO SEPARATE ELEOCHARIS CELLULOSA, E. MUTATA, AND E. SPIRALIS}

1a. Culms more or less terete to obscurely 3-angled (never triquetrous) distally; floral scales (3.6-)4.2-4.9(-5.3) mm long; achene apex gradually narrowed into a stout spongy region; perianth bristles usually smooth or rarely finely to coarsely retrorsely

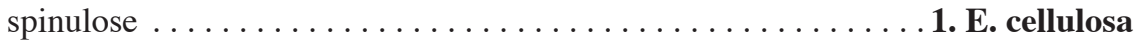

b. Culms triquetrous to trigonous (rarely obscurely 3-angled or terete) distally; floral scales (2.3-)2.8-4(-4.8) mm long; achene apex slightly constricted at the summit into a hard annular thickening; perianth bristles retrorsely spinulose (sometimes

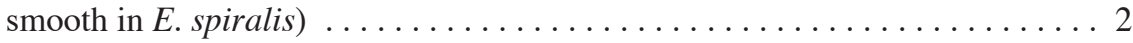

2a. Achenes with c. 20 longitudinal rows of transversely oblong cells; perianth bristles coarse-retrorsely spinulose, most exceeding the tubercle; floral scales ovate to broadly ovate, apex broadly rounded. - New World tropics and Sub-Saharan Africa ........................ mutata

b. Achenes with c. 17 longitudinal rows of transversely linear cells; perianth bristles irregularly spinulose or sometimes smooth, usually few surpassing the achene; floral scales obovate to very widely obovate, apex truncate to broadly rounded. - Oceania, Southeast Asia, Madagascar . . . . . . . . . . 3. E. spiralis

\section{Eleocharis cellulosa Torr. - Fig. 1; Map 1}

Eleocharis cellulosa Torr. (1836) 298. - Type: Ingalls s.n. (holo NY; iso GH), USA, Mississippi, Bay St. Louis.

Scirpus dictyospermus Wright in Sauvalle (1871) 79. - Type: Wright 3763 (holo GH; iso K, NY, P), Cuba.

Plants perennial. Roots coarse, fibrous, dark grey-brown to maroon, tubers rarely seen except in carefully collected plants; rhizomes long, 1-4 mm thick, scales to $6 \mathrm{~mm}$ long. Culms terete or rarely obscurely 3-angled to subtrigonous distally (especially when emergent), (39-)46-81(-97) $\mathrm{cm}$ by (0.9-)1.4-2.7(-3.5) $\mathrm{mm}$, soft to hard, internally spongy, with incomplete transverse septa, longitudinally striate when dry, shiny and smooth when fresh, light green. Leaves 2 , reduced to sheaths, apically oblique, apex 

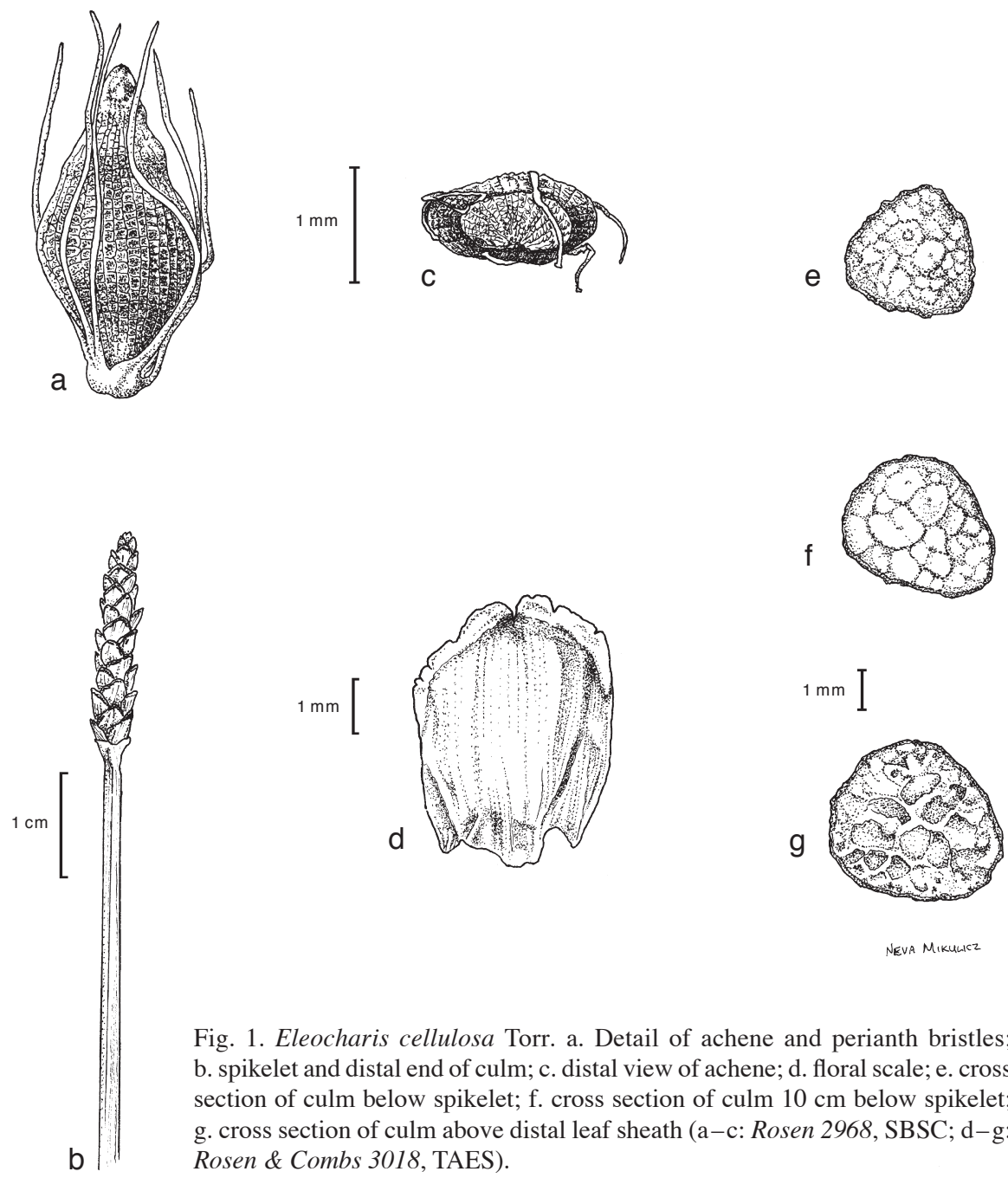

NEVA MikuLCZ

Fig. 1. Eleocharis cellulosa Torr. a. Detail of achene and perianth bristles; b. spikelet and distal end of culm; c. distal view of achene; d. floral scale; e. cross section of culm below spikelet; f. cross section of culm $10 \mathrm{~cm}$ below spikelet; g. cross section of culm above distal leaf sheath (a-c: Rosen 2968, SBSC; d-g: Rosen \& Combs 3018, TAES).

acute to acuminate, membranous, loose, friable, maroon-chestnut to cinnamon (orangish) basally, brownish distally, apex of upper sheath usually extended into a soft awn to 6 mm long. Spikelets cylindric, obtuse, proximal (1-)2-9(-10) scales empty, first scale amplexicaul and appearing as continuation of culm, (13-)24.4-43(-52) by (2.5-)3.54.6(-5.5) $\mathrm{mm}$; floral scales appressed to loosely ascending upon drying, ovate to broadly ovate, apex broadly rounded, distal $0.1-0.4 \mathrm{~mm}$ hyaline-erose, central area broadly keeled from base to near middle, $(3.6-) 4.2-4.9(-5.3)$ by $(2.2-) 2.8-3.5(-4) \mathrm{mm}$, with many fine cellular-lineate veins, midvein evident only in adaxial view, centrally indurate, stramineous, adaxially sparsely to densely red-maculate, abaxially sparsely red-maculate with a dark reddish brown band near apex. Flowers with (5-)6-7(-8) perianth bristles; bristles straight-tortuous, narrow to somewhat broad and strap-shaped proximally (rarely a bristle present abaxially that is variously forked only near the tip 
to nearly to the base), smooth or infrequently minutely nodulose (dark brown nodules seen only at high magnification), or bristles retrorsely spinulose nearly to base in some Caribbean plants, bristles 0.6-1.4 times achene length, stramineous, spinules when present colourless, $0.03-0.08 \mathrm{~mm}$ long; stamens 3; anthers 1.4-2 mm long, yellow to reddish brown; style 3-fid. Achenes biconvex, more or less obpyriform, obovate to very widely obovate, the apex constricted to \pm 0.6 times achene width, broadening again into a spongy beak of same texture and colour as the achene, $(1.5-) 1.6-2(-2.3)$ by (1.2-)1.4-1.6(-1.8) $\mathrm{mm}$, with (13-)16-19(-23) longitudinal rows of deeply pitted transversely oblong cells visible through transparent periclinal layer on each achene face, dull, cream coloured, maturing to lustrous amber or occasionally light brown; beak usually tapering apically or sometimes the central region spongy and the sides compressed (rarely appearing annulate as in E. mutata), $(0.2-) 0.4-0.8(-1.1) \mathrm{mm}$ high; tubercle usually distinct at high magnification or sometimes so gradually merging with beak as to be scarcely distinguishable from it, (0.1-)0.2-0.4(-0.6) $\mathrm{mm}$ tall, dark brown.

Distribution - Eleocharis cellulosa is a strictly American species. In the United States, currently known from Alabama, Arkansas, Florida, Georgia, Louisiana, Mississippi, North Carolina, South Carolina, and Texas. In México from the states of Campeche, Coahuila, Nayarit, Nuevo Leon, Quintana Roo, Tabasco, Tamaulipas, Veracruz, and Yucatan. In Central America from Guatemala, Belize, Honduras, and Nicaragua. Widespread in the Caribbean Basin with records from Bahama Archipelago, Bermuda, Cuba, Cayman Islands (Proctor 1984), Jamaica, Haiti, Dominican Republic, and Puerto Rico. In South America known only from Venezuela.

Phenology \& Ecology - Flowering from early June through early November in the south-eastern United States. In the tropics, E. cellulosa probably flowers year round. In

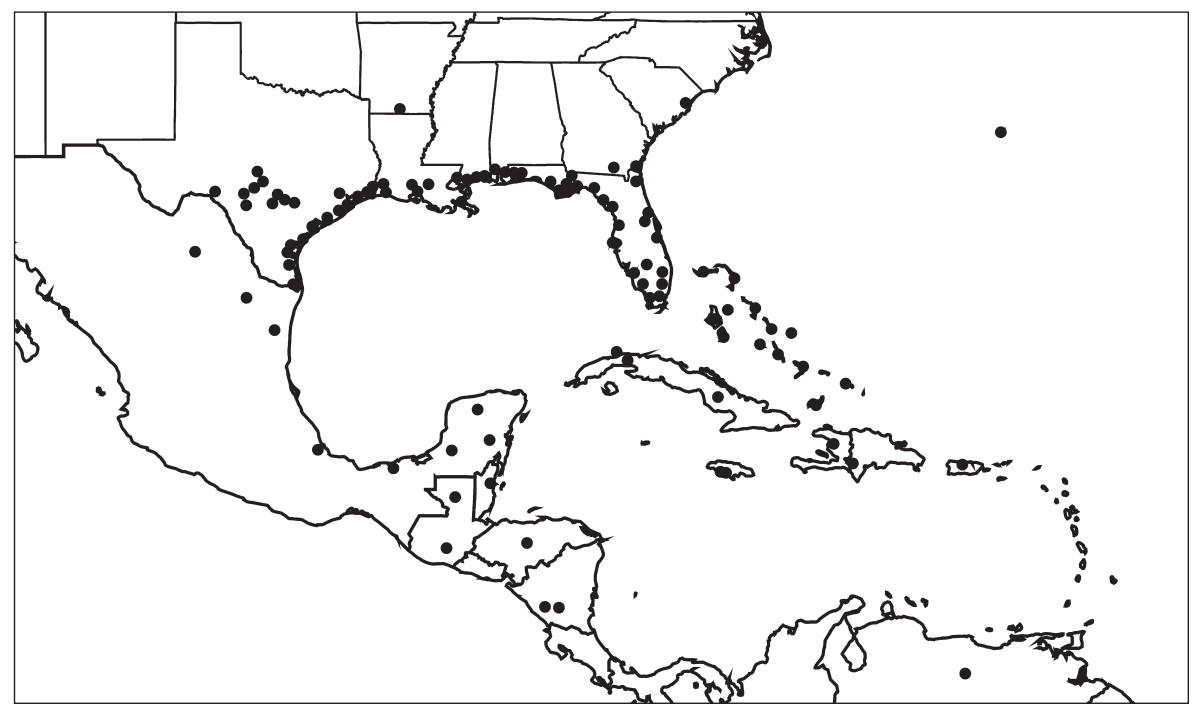

Map. 1. Distribution of Eleocharis cellulosa Torr. Each dot represents the general geographic location of one or more specimens. 
the south-eastern United States forming extensive stands in wetlands of the coastal plain, particularly near the coast although a few records occur from inland sites in Texas (the Edwards Plateau) and southern Arkansas. Eleocharis cellulosa is a dominant species of some wet-prairie vegetation types in the Florida Everglades (Loveless 1959). In the Caribbean, it occurs in mangrove swamps, fresh to salty marshes, and other coastal wetland habitats.

\section{Eleocharis mutata (L.) Roem. \& Schult. - Fig. 2a-g; Map 2}

Eleocharis mutata (L.) Roem. \& Schult. (1817) 155. - Scirpus mutatus L. (1759) 867. - Limnochloa mutata (L.) Nees (1842) 101. - Type: Elmgren s.n. (lecto LINN), Jamaica.

Eleocharis scariosa Steud. (1855) 80. - Lectotype (designated here): Martius Herb. Fl. Bras. 229 (lecto P, barcode P00217667; isolecto E, GH, M, MO, NY, P), Brasil, Sebastiana.

Plants perennial. Roots coarse, fibrous, grey-brown to maroon, tubers rarely seen; rhizomes long, 2-5 mm thick, scales to $8 \mathrm{~mm}$ long. Culms triquetrous to trigonous, usually conspicuously so distally (rarely obscurely 3 -angled to terete), sometimes twisted in plants growing in desiccated wetlands, (31-)53.8-93(-116) $\mathrm{cm}$ by $(2.2-)$ 2.6-5.1(-8.5) $\mathrm{mm}$, soft to hard, internally spongy, with incomplete transverse septa, longitudinally striate when dry, shiny and smooth when fresh, dark green. Leaves 2 , reduced to sheaths, apically oblique, apex acute to acuminate, membranous, loose, friable, maroon-chestnut to cinnamon brown, apex of upper sheath usually extended into a soft awn to $5 \mathrm{~mm}$ long. Spikelets cylindric, obtuse (acute), at least proximal 2 or 3 (or 4) scales empty, first scale amplexicaul and appearing as a continuation of the culm, (12-)23-44(-66) by (3-)3.8-5.4(-8) $\mathrm{mm}$; floral scales appressed to weakly spreading upon drying, ovate to broadly ovate, apex broadly rounded, distal $0.2-0.3$ $\mathrm{mm}$ hyaline-erose, central area broadly keeled from base for $0.3-0.5$ the scale length, (2.8-)3.2-4(-4.8) by (1.9-)2.5-3.4(-4.8) $\mathrm{mm}$, with many fine cellular-lineate veins, midvein evident only in adaxial view, indurate, stramineous, abaxially red-maculate or more frequently with a dark band near apex, adaxially red-maculate. Flowers with (5-)6-8 perianth bristles; bristles straight-tortuous, narrow to somewhat broad and strap-shaped proximally, retrorsely spinulose nearly to the base, mostly exceeding achene, stramineous, margins and spinules sometimes dark reddish; stamens 3 ; anthers 1.3-2 mm long, reddish brown; style 3-fid. Achenes biconvex, more or less obpyriform, obovate, or sometimes broadly elliptic, the apex constricted to \pm 0.6 times achene width, broadening again into a hard annulus of same texture and colour as the achene, $(1.2-) 1.3-1.6(-1.9)$ (not including annulus or tubercle) by $(1-) 1.1-1.4(-1.8) \mathrm{mm}$, with c. 20 longitudinal rows of deeply pitted transversely oblong cells visible through transparent periclinal layer on each achene face, dull, cream coloured, maturing to lustrous olive-yellow (amber); annulus transversely oblong and sometimes tapering apically, transversely rhombic when viewed distally, (0.05-)0.09-0.18(-0.3) $\mathrm{mm}$ high; tubercle dorsiventrally compressed, triangular (very shallowly triangular), well formed to withered, distinct or sometimes appearing to merge with annulus or shouldered by it, $(0.15-) 0.3-0.5(-0.9)$ by $0.4-0.8 \mathrm{~mm}$, dark brown.

Distribution - In the United States known only from south-eastern Texas. In México from Campeche, Chiapas, Coahuila, Colima (Revillagigedo Islands), Guerrero, Jalisco, Quintana Roo, Tabasco, Tamaulipas, Veracruz, and Yucatan. In Central America from 


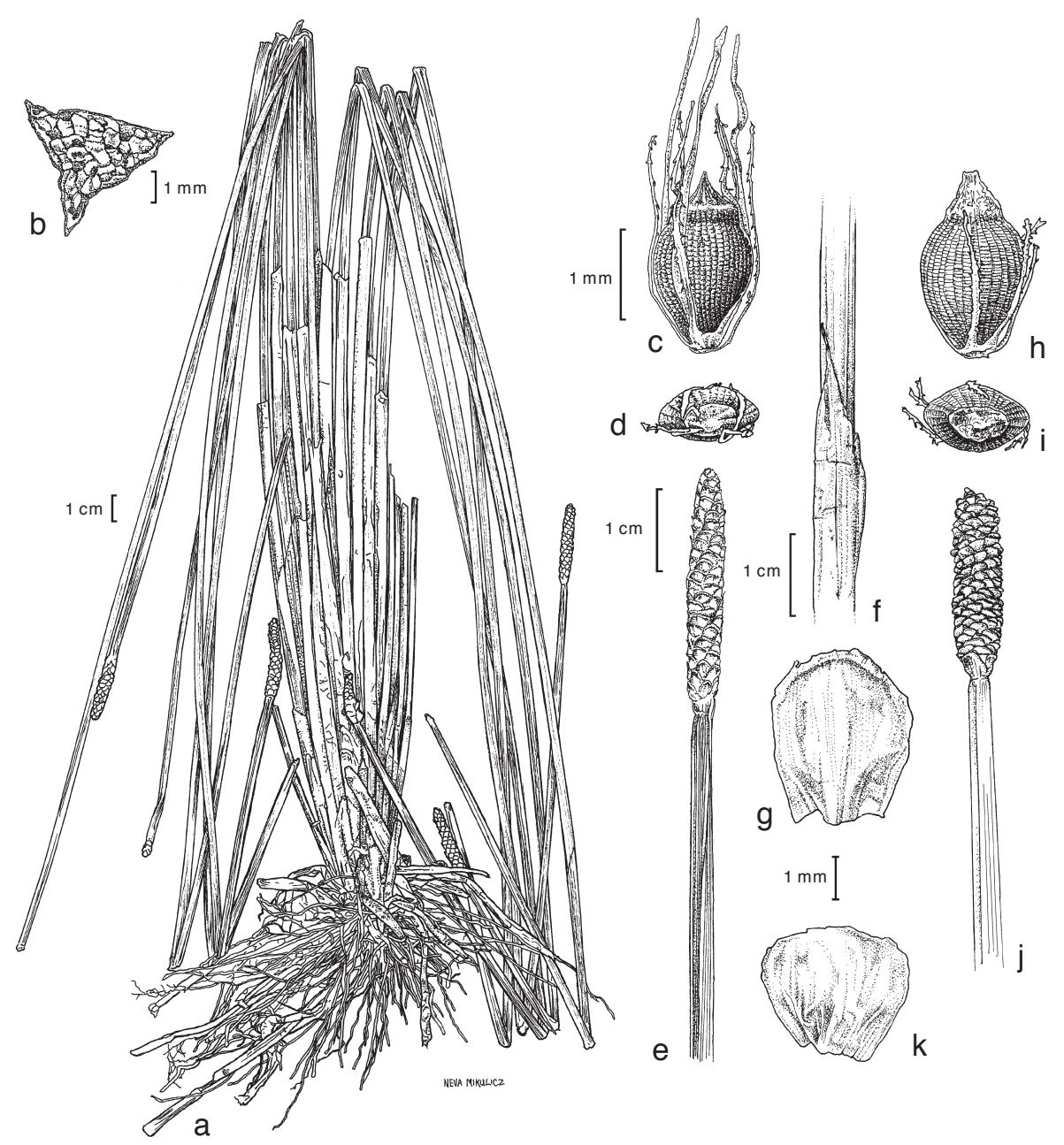

Fig. 2. a-g: Eleocharis mutata (L.) Roem. \& Schult. a. Habit; b. cross section at distal end of culm below spikelet; c. detail of achene and perianth bristles; d. distal view of achene; e. spikelet and distal end of culm; f. detail of apex of upper sheath; g. floral scale. - h-k: E. spiralis (Rottb.) Roem. \& Schult. h. Detail of achene and perianth bristles; i. distal view of achene; j. spikelet and distal end of culm; k. floral scale (a-g: Rosen 2614, MICH; h-k: Clemens 9716, K).

Guatemala, Belize, Honduras, Nicaragua, Costa Rica, Panama, and Clipperton Island. In the Caribbean Basin known from Bahama Archipelago, Cuba, Cayman Islands, Jamaica, Haiti, Dominican Republic, Puerto Rico, Virgin Islands, Leeward Islands, Windward Islands, and southern Netherlands Antilles. In South America known from Brazil, Colombia, Ecuador (including the Galápagos Archipelago), French Guiana, Guyana, Paraguay, Surinam, Tobago, Trinidad, and Venezuela. In Tropical Africa from Angola, Congo, Liberia, Pemba, Senegal, Sierra Leone, South Africa, and Togo. Some Puerto Rican specimens with perianth bristles thin and spinulose only near the tips and 


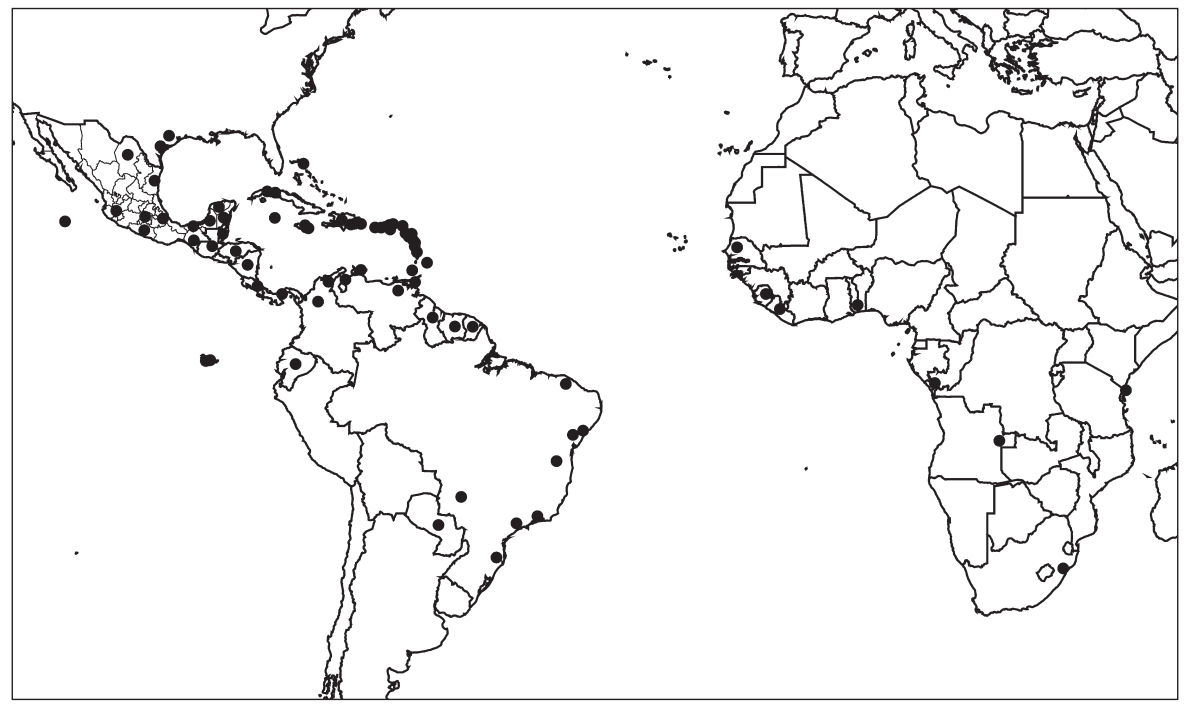

Map. 2. Distribution of Eleocharis mutata (L.) Roem. \& Schult. Each dot represents the general geographic location of one or more specimens.

the culms terete may be influenced by E. cellulosa, or may represent an undescribed species. Two specimens from southern México with terete culms, floral scales with distinctly raised veins, perianth bristles that are stiff (not tortuous) and very coarsely retrorsely spinulose, and achene epidermal cells that are elongated may represent an undescribed species. Formal recognition of these forms is best delayed until more material can be studied.

Phenology \& Ecology - Flowering year round and occurring in openings in mangrove swamps, fresh to salty marshes, brackish lagoons and inlets, inter-dune ponds, riverine wetlands, wet clear-cuts, and other coastal wetland habitats reportedly from $0-1200 \mathrm{~m}$.

Uses - Reported as a forage and fibre crop and rice field weed by Simpson \& Inglis (2001) and observed as forage for horses and cattle in southern México (Rosen, pers. obs. 2006). Dried culms used for pack-saddle pads and sleeping mats in Galápagos Archipelago (Stewart 1911).

\section{Notes on typification of Scirpus mutatus and lectotypification of Eleocharis scariosa}

Browning et al. (1997) reported the 'type' of Eleocharis mutata as being at LINN, but cited no specific specimen. This raises the issue of whether the name has been validly lectotypified according to current procedures outlined in the International Code of Botanical Nomenclature (McNeill et al. 2006). Cafferty \& Jarvis (2004) handled identical predicaments for several species of sedges by ascribing lectotype to a specific specimen. However, Mark Spencer (BM, pers. com.) suggested that since there is only one specimen of E. mutata at LINN known to have been associated with Linnaeus 
('71.2'), it seems prudent and conservative to accept the citation by Browning et al. (1997) as lectotypification for the time being. The inscription 'mutatus' on the specimen was written by Linnaeus, and the plant fits his description.

Eleocharis scariosa was first described by Steudel based on 'Nees in Mart. hrbr. Nr. 229'. Both Nees and Martius are often cited as the collector (e.g., Svenson 1929). Nees could not be the collector because the famous German botanist (and friend of Martius) never left Europe (Hajo Esser, M, pers. com.). Most collections made by Martius are unnumbered, and if numbered by him only go up to 3320 and are always located at $\mathrm{M}$ (Hajo Esser, M, pers. comm.). Low numbers (1-500, as is the case with E. scariosa) often refer to Martii Herbarium Florae Brasiliensis, a set of Brazilian plants that Martius received from other collectors and distributed widely, usually with many duplicates. Since one can never be certain who the collector was, the type collections of E. scariosa should be cited as Martius Herb. Fl. Bras. 229, with Martius as the editor, not the collector (Hajo Esser, M, pers. comm.). The Herb. Fl. Bras. has two meanings: It is the set of plants that Martius distributed, and also a publication of several parts in Flora (Beibl.) in c. 1840-1841, and is the publication on the herbarium specimens of the same name. One can assume that Steudel was referring to this publication and probably to the parts on Eleocharis in this publication written by Nees. Presumably, Nees was not cited as collector, but as author. Photos of two duplicates of Martius Herb. Fl. Bras. 229 at P were provided by Caroline Cloup. Specimen \#P00217667 is considered by the staff at P to be most reliably associated with Steudel, and is selected as lectotype.

\section{Eleocharis spiralis (Rottb.) Roem. \& Schult. - Fig. 2h-k; Map 3}

Eleocharis spiralis (Rottb.) Roem. \& Schult. (1817) 155. - Scirpus spiralis Rottb. (1773) 45. - Limnochloa spiralis (Rottb.) Nees. (1834) 114. - Lectotype (designated here): Koenig s.n. 1834 (lecto C, barcode L 56/2004 No 55; iso-lecto C), India, Malabaria.

Eleocharis compacta R.Br. (1810) 224. - Scirpus compactus (R.Br.) Poir. (1817) 102. - Lectotype (designated here): Brown 5934 (lecto BM, barcode BM000901117; iso-lecto BM, K), Australia, Northern Territory.

Eleocharis austro-caledonica auct. non Vieillard (1862) xvi: Svenson (1939) 41.

Plants perennial. Roots coarse, fibrous, grey-brown, tubers absent; rhizomes long, 2-3 $\mathrm{mm}$ thick, scales to $7 \mathrm{~mm}$ long. Culms trigonous to nearly triquetrous, conspicuously so to near base in some specimens, or only distally or sometimes obtusely trigonous to terete, coarse, (29-)43.9-71(-91.5) $\mathrm{cm}$ by $(1.4-) 1.8-2.8(-3.6) \mathrm{mm}$, soft to hard, internally spongy, with incomplete transverse septa, longitudinally striate when dry. Leaves 2, reduced to sheaths, apically oblique, apex acute to acuminate, membranous, loose, friable, often conspicuously and variably blotched from maroon, pink, to cinnamon brown, apex of upper sheath usually extended into a soft awn to $6 \mathrm{~mm}$ long. Spikelets cylindric, obtuse (acute), proximal 2 or 3 scales empty, first scale obtuse, amplexicaul, appearing as continuation of culm, (11-)18.7-32.6(-41) by (3-)3.8-5.2(-6) $\mathrm{mm}$; floral scales appressed, obovate to very widely obovate, apex truncate to broadly rounded, distal $0.2-0.3 \mathrm{~mm}$ hyaline-erose, central area distinctly broadly keeled from base to near middle, $(2.3-) 2.8-3.8(-4.2)$ by $(2-) 2.4-3.3(-3.7) \mathrm{mm}$, with many very fine cellular-lineate veins, midvein evident only in adaxial view, a central obtriangular region indurate, cartilaginous to hyaline along sides, stramineous, scarcely abaxially red-maculate and sometimes with a dark band near apex, conspicuously adaxially red- 
maculate. Flowers with (4-)5-7(-8) perianth bristles; bristles straight-tortuous, narrow, irregularly spinulose to smooth, usually half or fewer exceeding achene, stramineous, margins and spinules sometimes dark reddish; stamens 3; anthers (1.1-)1.3-1.7(-1.8) mm long, reddish brown; style 3-fid. Achenes biconvex or with (abaxial?) central bulge, obovate, or sometimes broadly obovate, apex constricted to \pm 0.6 times achene width, broadening again into hard annulus of same texture and colour as achene, (1.2-)1.3-2.1 by (0.93-)1.04-1.3(-1.4) mm, with c. 17 longitudinal rows of transversely linear cells with inconspicuous longitudinal interstitial ridges visible through transparent periclinal layer on each achene face, dull buff or cream coloured, maturing through amber to lustrous dark brown; annulus narrowly oblong (indistinct) or prolonged and tapered, merging into a short conical tubercle, sometimes very similar in aspect to E. cellulosa, 0.1-0.2(-0.3) mm high; tubercle dorsiventrally compressed, triangular, well formed to withered, distinct or sometimes appearing to merge with prolonged and tapered annulus, $(0.3-) 0.4-0.6(-0.7)$ by $(0.4-) 0.5-0.6(-0.8) \mathrm{mm}$, dark brown.

Distribution - In Southeast Asia, known from China, India, Malaysia, Philippines, Sri Lanka, Thailand, and Vietnam. In Oceania known from tropical and subtropical regions of Australia (Northern Territory and Queensland), New Caledonia, and Papua New Guinea. In Africa known from the Island of Mauritius, and reported by Svenson (1939) from Madagascar. Reports of E. spiralis for the New World (e.g., Koyama 1985, Simpson \& Koyama 1998) appear to be based on misidentified specimens of E. mutata. We have seen no authentic specimens of E. spiralis from the New World.

Phenology \& Ecology - Eleocharis spiralis flowers year round and usually occurs at low elevations in extensive stands on clayey to peaty soils in Melaleuca and mangrove swamps, saline flats, brackish to saline marshes, riverine wetlands, and other coastal wetland habitats (Cowie et al. 2000).

Uses - In Indramaju, Java, reportedly used for making mats (Kern 1974).

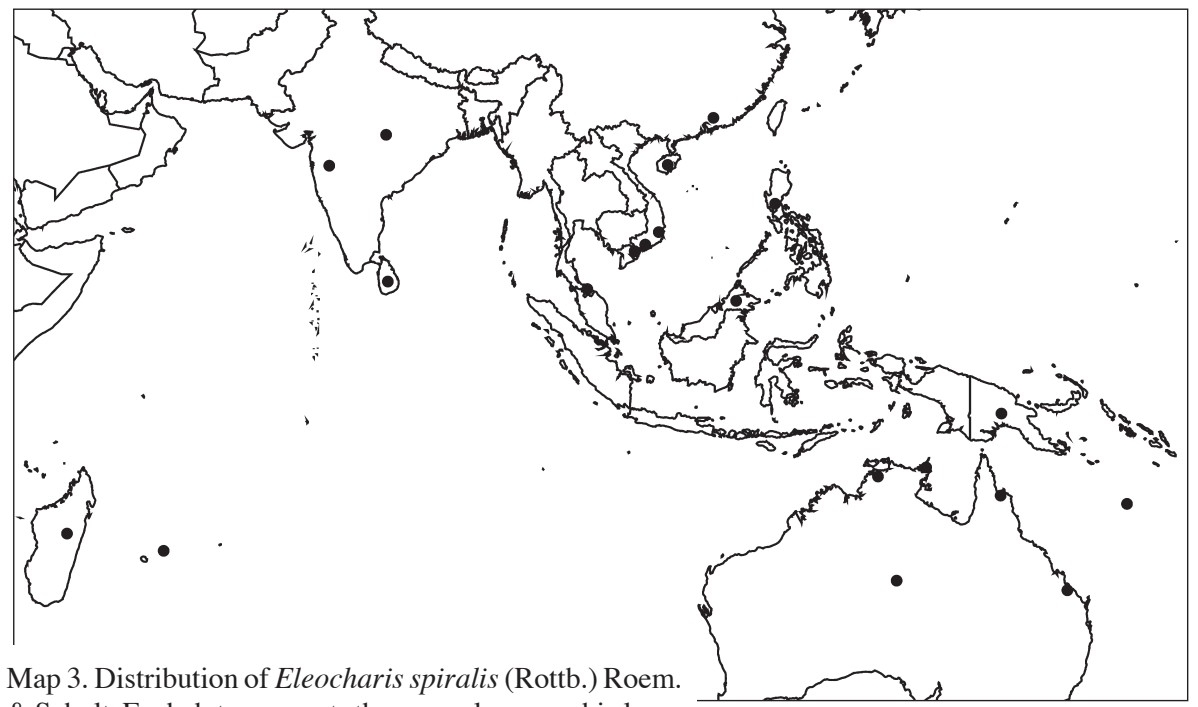

\& Schult. Each dot represents the general geographic location of one or more specimens. 


\section{Notes on lectotypification of Eleocharis spiralis and Eleocharis compacta}

Eleocharis spiralis was first described and illustrated under Scirpus by Rottboell based on plants sent to him by Koenig from India. The protologue designates no type and the description is accompanied by a detailed illustration of a sterile specimen. Roemer \& Schultes (1817) transferred the name to Eleocharis without indicating a type. Although Brown is sometimes recognized as author of this combination, he merely indicated the correct placement of S. spiralis in Eleocharis. The Koenig Herbarium is housed at C, from which five specimens of Eleocharis spiralis collected by Koenig were received. Accession \# L56/2004 No 55 is traditionally thought to have been associated with the protologue of Scirpus spiralis Rottb. (Ib Friis, C, pers. comm.). Since it critically matches the various elements of the protologue, it is herein designated as lectotype.

Eleocharis compacta is based on Brown 5934 from Australia. Upon Brown's death in 1858 , his personal herbarium was acquired by the British Museum and duplicates were distributed to Kew, Edinburgh, Melbourne, and Sydney (Stearn 1960). Stearn (1960) suggested lectotypes for species described by Brown be sought at BM. We have examined photos of two specimens of Brown 5934 from BM. A sheet (BM000901117) inscribed on the back "Nova Hollandia Ora Septentrionalis Mr. Brown" is herein designate as lectotype as recommended by Stearn (1960), since it is likely the specimen Brown selected for the public collection. A second sheet from BM bears a blue printed label typical of Brown's duplicates distributed by the Bennett bequest (Stearn 1960). Two specimens of Brown 5934 on loan from K, although immature, are otherwise referable to E. spiralis and are isolectotypes.

\section{Confusion surrounding Eleocharis austro-caledonica}

Svenson (1929) treated Eleocharis austro-caledonica Vieill. (based on Vieillard 1453) as a synonym of $E$. dulcis, and then later under $E$. spiralis without explanation (Svenson 1939). Our research has resolved the confusion surrounding Vieillard 1453 and how E. austro-caledonica relates to E. dulcis and E. spiralis. A duplicate of Vieillard 1453 was received on loan from BM. Photographs of three sheets of Vieillard 1453 (one mixed with 1455) were also sent from P (where Vieillard's types are located). All of the specimens at $\mathrm{P}$ are annotated by Guillaumin as E. dulcis. An examination of the photographs shows the culms are conspicuously septate, and the spikelet characteristics are of E. dulcis, not E. spiralis. However, the duplicate of Vieillard 1453 from BM is immature, but is without a doubt E. spiralis. Thus, the elements of Veillard 1453 cited as type of E. austro-caledonica, comprise a mixed collection. In the absence of an annotation as type of a particular specimen by Veillard, it is currently not possible to determine exactly to which element he intended to apply the name. However, the protologue describes plants a meter or more high, which is probably too tall for E. spiralis. Since the three specimens at $\mathrm{P}$ are referable to $E$. dulcis, it is prudent to select one of these as type and to treat E. austro-caledonica as a synonym of E. dulcis.

\section{ACKNOWLEDGEMENTS}

We are grateful to the staff of the herbaria cited for loan of specimens for study. We are especially grateful to Caroline Cloup (P), Hajo Esser (M), Ib Friss (C), Kanchi Gandhi (GH), and Mark Spencer and Peter Stafford (BM) and the curatorial and library staff of many other herbaria for their assistance 
with questions about the disposition of type specimens, literature, and nomenclature. The first author is grateful to Socorro González-Elizondo for sharing her expertise and also for facilitating field work in México. The first author is also grateful to José Marcos Pinedo Reyes for his assistance in the field in México. We are grateful to Neva Mikulicz for preparing the excellent illustrations. The helpful comments of the editor and the anonymous reviewer improved the manuscript and are greatly appreciated. Financial support for the first author was provided by the Frank W. Gould Award for Graduate Student Research in Plant Systematics and the Dr. Harry Wayne Springfield Graduate Student Endowment. Financial support for field work by R. Carter was provided by the Valdosta State University Foundation.

\section{REFERENCES}

Brown, R. 1810. Prodromus florae Novae Hollandiae. Hafner Pub. Co., New York.

Browning, J., K.D. Gordon-Gray \& C.J. Ward. 1997. Studies in Cyperaceae in Southern Africa 32: Eleocharis subgenus Limnochloa section Limnochloa. S. African J. Bot. 63, 4: 172-184.

Cafferty, S. \& C.E. Jarvis. 2004. Typification of Linnaean plant names in Cyperaceae. Taxon 53: 177-181.

Cowie, I.D., P.S. Short \& M. Osterkamp Madsen. 2000. Floodplain flora: A flora of the coastal floodplains of the Northern Territory, Australia. ABRS, Canberra.

González-Elizondo, M.S. \& P.M. Peterson. 1997. A classification of and key to the supraspecific taxa in Eleocharis (Cyperaceae). Taxon 46: 433-449.

González-Elizondo, M.S. \& A.A. Reznicek. 1996. New Eleocharis (Cyperaceae) from Venezuela. Novon 6: 356-365.

González-Elizondo, M.S. \& J.A. Tena-Flores. 2000. Eleocharis (Cyperaceae) in the New World. In: K.L. Wilson \& D. A. Morrison (eds.), Monocots: systematics and evolution: 637-643. CSIRO Publishing, Australia.

Holmgren, P.K., N.H. Holmgren \& L.C. Barnett. 1990. Index herbariorum Part I: The herbaria of the world. New York Botanical Garden, New York.

Kern, J.H. 1974. Cyperaceae. Flora Malesiana, Ser. I, Vol. 7, 3: 435-753. Noordhoff, Leyden.

Klimko, M. 1988. Systematic studies on Eleocharis acutangula (Roxb.) Schult. and Eleocharis variegata (Poir.) Presl. Bull. Soc. Amis Sci. Lett. Poznan 27: 69-79.

Koyama, T. 1985. Cyperaceae. In: M.D. Dassanayake \& F.R. Fosberg (eds.), Flora of Ceylon, Vol, 5: 125-405. Amerind Publishing Co. Pvt. Ltd., New Delhi.

Linnaeus, C. 1759. Systema Naturae, Tomus II, editio decima, reformata. Laurentii Salvii, Stockholm.

Loveless, C.M. 1959. A study of the vegetation in the Florida Everglades. Ecology 40: 1-9.

McNeill, J., F.R. Barrie, H. M. Burdet, V. Demolin, D.L. Hawksworth, K. Marhold, D.H. Nicolson, J. Prado, P.C. Silva, J.E. Skog, J.H. Wiersema \& N.J. Turland. 2006. International code of botanical nomenclature (Vienna Code). Regnum Veg. 146.

Nees von Esenbeck, C.G.D. 1842. Cyperographia sive descriptio in Brasilia provenientium. In: K.F.P. von Martius (ed.), Flora Brasiliensis, Vol. II, Part I: 1-226. Stuttgartiae \& Tubingae, sumptibus J.G. Cottae.

Nees von Esenbeck, C.G.D. 1834. No. III. Cyperaceae indicae. Praecipue juxta herbaria Wrightii, Wallichii, Roylei et Lindleyi. In: R. Wright (ed.), Contributions to the botany of India: 69-129. London.

Poiret, J.L.M. 1817. Scirpus. In: J.B.A.P. de Monnet de Lamarck et al., Encyclopédie Méthodique. Botanique. Suppl. 5: 90-106. Paris.

Proctor, G.R. 1984. Flora of the Cayman Islands. Her Majesty's Stationary Office, London.

Roalson, E.H. 1999. Eleocharis yecorensis (Cyperaceae), a new species of spike-sedge from México. Aliso 18: 57-60.

Roemer, J.J. \& J.A. Schultes. 1817. Systema Vegetabilium. Vol. 2. Stuttgart.

Rosen, D.J. 2006. A systematic study of select species complexes of Eleocharis subgenus Limnochloa (Cyperaceae). PhD thesis. Texas A\&M University, College Station, USA. 
Rosen, D.J. \& S.L. Hatch. 2007. A new species of Eleocharis subg. Limnochloa (Cyperaceae) from Bolivia. Brittonia 59: 377-379.

Rottboell, C.F. 1773. Descriptionum et iconum rariores et pro maxima parte novas plantas illustrantium liber primus. Hafniae, Sumptibus Societatis Typographicae.

Sauvalle, F.A. 1871. Flora Cubana. Anales Acad. Ci. Med. Habana.

Simpson, D.A. \& C.A. Inglis. 2001. Cyperaceae of economic, ethnobotanical and horticultural importance: a checklist. Kew Bull. 56: 257-360.

Simpson, D.A. \& T. Koyama. 1998. Cyperaceae. In: T. Santisuk \& K. Larsen (eds.), Flora of Thailand, Vol. 6, part 4: 284-292. Diamond Printing Co., Thailand.

Stearn, W.T. 1960. An introduction to Robert Brown's Prodromus Florae Novae Hollandiae. In: R. Brown, Prodromus florae Novae Hollandiae et Insulae van-Diemen, facsimile edition: v-lii. Cramer, Weinheim.

Steudel, E.G. 1855. Synopsis plantarum Cyperacearum. Stuttgart.

Stewart, A. 1911. A botanical survey of the Galápagos Islands. Proc. Calif. Acad. Sci. IV, 1: 7-288.

Svenson, H.K. 1929. Monographic studies in the genus Eleocharis I. Rhodora 31: 121-135, 152-163, 167-191, 199-219, 224-242.

Svenson, H.K. 1939. Monographic studies in the genus Eleocharis V. Rhodora 41: 1-19, 43-77, 90-110.

Torrey, J. 1836. Monograph of North American Cyperaceae. Ann. Lyceum Nat. Hist. New York 3: $239-448$.

Trevisan, R. \& I.I. Boldrini. 2006. A new species of Eleocharis R. Brown (Cyperaceae) from Southern Brazil. Novon 16: 155-157.

Vieillard, E. 1862. Plantes utiles de la Nouvelle-Calédonie. Ann. Sci. Nat., Bot. sér. 4, 16: 28-76. 